\title{
ARSIP DAN PENJAJAHAN PIKIRAN
}

\author{
Tedy Harnawan*
}

\section{"The most effective way to destroy people is to deny and obliterate their own understanding of their history." - George Orwell}

Sejarah adalah masa lalu, sedangkan masa lalu sudah lenyap. Dalam rangka melakukan penelitian sejarah, masa lalu adalah semesta yang sudah hilang dan terlewati sehingga kemungkinan untuk mendekat dengan peristiwa masa lampau adalah mencari jejak dan peninggalan sejarah. Perpustakaan seringkali menjadi ruang paling esensial yang terlintas dalam pikiran seorang peneliti. Apa yang dibayangkan pertama kali oleh penelitian selalu tentang arsip, yaitu sumber tertulis yang berbentuk catatan-catatan, koran, majalah, surat-menyurat atau berbagai macam bentuk arsip yang lain. Namun, bagaimana jika ternyata arsip merupakan sebuah teks yang direkayasa di masa lalu? Apakah mungkin mencapai suatu objektifitas sejarah dengan menggunakan arsip yang subjektif?

Dalam bahasa Yunani, "arsip" berasal dari kata arkheion yang berarti rumah, domisili, alamat atau kediaman para archons, yaitu golongan yang memberikan perintah. Warga yang memegang dan menandakan kekuatan politik dianggap memiliki hak untuk membuat atau mewakili undang-undang. Namun, mereka mengajukan dokumen resmi yang sudah lebih dulu dibuat di dalam rumah mereka yang tidak diketahui secara publik. Dalam tahap ini, ada sesuatu yang tersembunyi, disembunyikan dan disebarkan. Arcons berperan sebagai penjaga dokumen. Mereka tidak hanya memastikan keamanan fisik dari apa yang disimpan dan isinya, namun juga diberi hak dan kompetensi hermeneutik. Mereka memiliki kekuatan untuk menafsirkan arsip. Secara kronologis, proses untuk menjadi arsip telah melewati proses kreasi, seleksi dan pengamanan yang ketat. Menurut Derrida, "archive" juga berasal dari kata arkhe yang mengandung dua arti penting sekaligus, yaitu permulaan (commencement) yang memiliki nilai historis dimana ada sesuatu yang mengawali, dan perintah (commandement) dimana ada wewenang dan kekuasaan. Ada dua unsur yang harus dikritik dalam arsip, yaitu adanya unsur orisinalitas namun juga ada unsur kekuasaan di dalamnya (Derrida, 1995, hlm 9).

\section{Dekolonisasi Pemikiran}

Pada tahun 1999, terbit sebuah buku berjudul Decolonizing Methodologies, Research and Indigenous Peoples yang ditulis oleh Linda Tuhiwai Smith dan menjadi bacaan wajib akademisi di seluruh dunia. Linda Tuhiwai Smith mengkritik dunia penelitian yang mengacu pada paradigma poskolonial yang memandang kolonialisme sebagai "pencipta sejarah dan realitas

\footnotetext{
* Mahasiswa Pascasarjana Sejarah, Universitas Gadjah Mada 2017. harnawantedy@ gmail.com
} 
yang menikam rasa kemanusiaan paling dalam". "Arsip" sebagai suatu bentuk penjajahan pikiran yang harus dipahami sebagai produk pengetahuan, bukan terbatas pada teks tertulis atau benda-benda artefak tetapi juga produksi pengetahuan atas pikiran. "Arsip" memiliki struktur, pranata dan nilai-nilai kebudayaan tertentu. Jika mengacu pada Derrida, "arsip" memiliki konsep yang lebih luas. Sebagai seorang perempuan yang memiliki keturunan asli orang Maori di Selandia Baru, ia mengajukan kritik utama yang ditujukan bagi para peneliti lokal yang ingin melakukan penelitian akademik yang terjebak dalam alam pengetahuan Barat. Baginya, sejarah sebagai pengetahuan ilmiah telah melewati praktik-praktik rasisme dan eksploitasi terhadap orang-orang terjajah. Sementara itu, Foucault berpendapat jika apa yang disebut sebagai peradaban Barat adalah pengakuan dan pendefinisian ulang atas pandangan atas pengalaman-pengalaman kulit hitam (Smith, 2005, hlm. 48). Peradaban Barat itu berupa pengetahuan, filsafat dan definisi yang disebut sebagai "arsip kultural".

Para peneliti yang meneliti suku-suku pedalaman menciptakan dunia yang terpisah antara bangsa penjajah dan bangsa terjajah (indigenous) atas nama pengetahuan. Akibatnya, hasil penelitian lebih mengandung tujuan tertentu karena bangsa terjajah selalu dianggap bodoh dan terbelakang (savage). Pertentangan antara indigenous dan pengetahuan Barat yang menempatkan diri sebagai budaya superior di atas pengetahuan pribumi, saling bertolak belakang. Maka, arsip-arsip yang ditulis dan diproduksi oleh kolonialisme harus mengalami dekonstruksi. Selama ini, sejarah kolonialisme hanya menerjemahkan orang-orang terjajah secara tidak utuh dan cenderung hanya melakukan kenikmatan cara pandang yang berjarak (voyeurism) karena berpandangan rasis, seksis dan etnosentris.

\section{Hierarki Arsip}

Tulisan lain yang juga penting adalah Laura Ann Stoler yang menguak "arsip" yang mempunyai dimensi hirarki kredibilitas. Dalam tulisannya, "In Cold Blood": Hierarchies of Credibility and the Politics of Colonial Narratives, jika "arsip" diartikan sebagai realitas sosial, maka "arsip" adalah realitas yang tidak utuh karena merupakan rekayasa yang memiliki unsur fakta dan fiksi di dalamnya. Ann Stoler menemukan arsip tentang surat-surat Frans Carl Valck, seorang Asisten Residen Sumatra Timur, mengenai pembunuhan keluarga Luhmann yang bekerja sebagai pemilik perkebunan di Deli yang ditulis sebelas hari setelah kejadian pada tanggal 28 Oktober 1876. Istri dan dua anaknya dibunuh oleh para pekerja yang sebelumnya dipekerjakan oleh keluarga Luhmann. Sebagai sebuah "arsip" yang diciptakan oleh pemerintah kolonial, Stoler mencoba menjelaskan tentang rekonstruksi pengetahuan mengenai kekerasan kolonial, pengetahuan budaya dan bagaimana arsip ditulis dan dibaca. Dalam surat tersebut, pembunuh dituduhkan kepada para pekerja kebun. Selama beberapa bulan, Valck dan pegawai sipil Belanda lainnya, personil militer, dan pekebun Eropa bertukar ratusan laporan yang mengungkapkan versi mereka sendiri tentang apa yang 
menyebabkan pembakaran, penggerebekan, dan pembunuhan di Pantai Timur Sumatra. Namun, yang menarik adalah bagaimana Valck dan agennya mengisi kesenjangan dalam pengetahuan mereka dengan dugaan yang masuk akal secara budaya, sehingga membuat cerita mereka persuasif dan relevan bagi khalayak kelas, gender, dan ras. Di sisi lain, representasi kultural para pekerja kebun diabaikan karena tidak mempunyai akses pengetahuan yang dipercaya oleh pemerintah kolonial.

Salah satu penguasaan pengetahuan adalah pemakaian bahasa yang secara tidak sadar telah dibiasakan sebagai pengetahuan umum. Proyek metodologi Barat yang menjadi ukuran atau tolak ukur penelitian seakan-akan telah diterima (taken for granted) karena bersifat rasional dan luar biasa efektif. Kolonialisme sebagai contoh, hanya mewariskan cara pandang imperialis bahkan kepada orang-orang pribumi yang kemudian memandang diri mereka sendiri sebagai objek kajian Barat.

“Apa yang pada awalnya cuma khayalan, opini atau penjelasan keliru tentang kehidupan dan adat-istiadat pribumi, meresap dengan cepat ke dalam bahasa kemudian dipakai sebagai cara untuk merepresentasikan bangsa pribumi." (Smith, 2005, hlm: 111). Bahasa adalah satu contoh penjajahan pengetahuan. Dalam sejarah kolonialisme Belanda, gundik (nyai) adalah perempuan pribumi yang dinikahi secara tidak sah pada zaman kolonial Belanda di Indonesia. Kita tidak pernah mengetahui sejak kapan istilah gundik digunakan atau apakah sebenarnya istilah ini memang muncul karena dominasi kekuasaan kolonial yang menciptakan sebuah konsep baru untuk mendefinisikan suatu objek tertentu. Mereka adalah perempuan-perempuan pribumi yang dinikahi (tidak resmi) oleh orang-orang Eropa dan sering hanya menjadi objek seksual dan sering mengalami kekerasan seksual. Gundik tidak memiliki warisan dan hanya dibutuhkan untuk menghasilkan anak-anak Indo yang kadang-kadang diangkat statusnya sebagai anak biologis jika ayah Eropanya mengakui.

Penciptaan terminologi atau bahasa berhubungan dengan penjajahan tubuh orang-orang yang terjajah. Penguasaan tubuh itu diwujudkan ke dalam bahasabahasa kolonialisme yang bias dan rasis. Gundik disebut juga sebagai buku (boek) atau kamus (woordenboek) yang berkaitan dengan fungsi mereka sebagai penerjemah atau pengajar bahasa pribumi kepada majikan atau suami mereka. Bahkan, dalam hal tertentu, gundik juga disebutkan secara berbeda-beda. Dalam buku Reggie Baay Nyai dan Pergundikan di Hindia Belanda, gundik atau nyai disebut dengan Moentji atau Mina. Moentji bermakna peyorasi yang merupakan pelesetan dari kata mondje yang berarti mulut kecil. Di dalam tangsi KNIL mereka disebut Sarina dan di perkebunan, mereka disebut Deli Kartina. Dalam bahasa Inggris, mereka menyebut guling dengan "Dutch wife" yang merujuk pada karakteristik kolonialisme Belanda yang mempraktikkan perbudakan perempuan. Pengetahuan Barat menciptakan klasifikasi-klasifikasi tertentu yang membuat 
garis tegas antara yang menjajah (colonizer) dan yang dijajah (colonized). Penggunaan istilah tersebut digunakan di dalam dunia intelektual oleh para sejarawan.

"Arsip" adalah sumber sejarah dimana masa lalu bisa direkonstruksi kembali. Namun, arsip seharusnya tidak diterima begitu saja sebagai klaim kebenaran tunggal. Sebagai usaha untuk mengurangi subjektifitas peneliti, "arsip" harus melewati proses kritik dan dekonstruksi dengan membandingkan dengan realitas-realitas yang lainnya.

\section{Daftar Pustaka}

Ann Laura Stoler, "In Cold Blood": Hierarchies of Credibility and the Politics of Colonial Narratives, Representations, No. 37, Special Issue: Imperial Fantasies and Postcolonial Histories (Winter, 1992), pp. 151-189.

Jacques Derrida dan Eric Prenowitz, “Archive Fever: A Freudian Impression”, Diacritics, Vol. 25, No. 2 (Summer, 1995), pp. 9-63.

Linda Tuhiwai Smith, Dekolonisasi Metodologi, (Yogyakarta: Insist Press, 2005).

Reggie Baay, Nyai \& Pergundikan di Hindia Belanda, (Depok: Komunitas Bambu, 2010). 